\title{
Approximate Annual Water Budgets of Two Chained Pinyon-Juniper Sites
}

\section{GERALD F. GIFFORD}

Highlight: Approximate annual water budgets for various pinyon-juniper treatments (chaining-with-windrowing, chaining-with-dehris-in-place, and natural woodland) have been compiled for a 3-year period near Milford, Utah, and for a 2-year period near Blanding, Utah. Results of the analysis indicate that most of the annual precipitation falling on each treatment is lost through evapotranspiration, with much of the balance being lost through interception. When runoff did occur, it was greatest from windrowed treatments and least from debris-in-place treatments.

Information regarding the water balance of semiarid plant communities is scarce. This paper brings together information from several individual studies on two chained pinyon-juniper (Pinus edulis-Juniperus osteosperma) sites in Utah to construct an approximate water balance for each of three treatments at each site: natural woodland, chaining-with-debris-in-place, and chaining-with-windrowing.

\section{Site Descriptions and Methods}

The water balance study was undertaken at two locations in southern Utah, one about 72 kilometers southwest of Milford and the other about 70 kilometers west of Blanding. The chaining treatmeris ( 12 to 16 hectares each) were performed during the fall of 1967 at both sites, and the areas fenced to exclude livestock. Chaining involves pulling a large anchor chain between two tractors to fell the pinyon and juniper trees. The windrowed areas (all debris pushed into windrows) were drill seeded with crested wheatgrass at 9.1 kilograms per hectare and the debris-in-place areas (debris left where it fell) were broadcast seeded at the same rate. A more detailed description of the sites and treatments has already been published (Gifford, 1973). Data are available for a 3-year period at Milford and for a 2-year period at Blanding. Methodology used in water balance calculations is described in the following subsections.

\section{Precipitation}

Precipitation was measured at each site using $20-\mathrm{cm}$ (8-inch) raingages. During the period of about June 6 to October 1 of each year, rainfall was measured using both recording and nonrecording gages. Nonrecording storage gages

\footnotetext{
Author is associate professor, range watershed science, Watershed Science Unit, Utah State University.

This study was conducted in cooperation with the Bureau of Land Management under contract 14-11-0008-2837. Journal Paper 1840, Utah Agricultural Experiment Station, Utah State University, Logan. Manuscript received April 6, 1974.
}

were used during the balance of each year. It is assumed that each treatment at either Milford or Blanding received the same annual precipitation (though slight variations did occur, especially in summer rainfall).

\section{Interception}

Interception was not measured directly on any treatment. For the woodland interception was calculated from equations presented by Collings (1966); on windrowed areas it was assumed that maximum interception amounted to $.10 \mathrm{~cm}(.04$ inch) for any given storm plus $4 \%$ of the total rainfall received during those times that recording gages were not in operation (Branson, Gifford, and Owen, 1972); and on the debris-in-place treatments it was assumed that interception was proportional to that intercepted on the windrowed treatments, depending on percent cover (tree, shrub, grass, and litter cover combined, maximum cover being $100 \%$ ).

$$
I_{D}=I_{W} \frac{C_{D}}{C_{W}}
$$

where $\mathbf{I}_{\mathrm{D}}$ represents interception in the debris-in-place treatment, $\mathbf{I}_{W}$ interception in the windrowed treatment, $\mathbf{C}_{D}$ is percent cover in the debris-in-place treatment, and $\mathbf{C}_{W}$ percent cover in the windrow treatment.

Within the woodland, Collings (1966) indicates that total water (TW) received at the ground surface may be expressed as:

$$
\mathrm{TW}=0.87 \mathrm{P}^{1.16}+0.09 \mathrm{P}^{1.25}
$$

where $\mathbf{P}$ is precipitation. This equation accounts for throughfall and stemflow, but it does not account for losses due to interception by litter on the soil surface, so the equation was modified slightly as follows:

$\mathrm{TW}=0.87 \mathrm{P}^{1.16}+0.09 \mathrm{P}^{1.25}-.03$,

where the .03 inch $(.08 \mathrm{~cm})$ was estimated interception loss due to pinyon-juniper litter. Interception was simply total precipitation $(P)$ received minus total water (TW) received at the mineral soil surface. Interception values in the woodland were calculated for each individual storm during the period June 6 to October 1 at each site. During the remaining period, when only storage gages were operating, interception was approximated at $17 \%$ of the precipitation received during a given measurement period (Skau, 1964).

\section{Runoff}

Runoff at both Milford and Blanding was measured using techniques described by Gifford (1973). These techniques involved use of .04 hectarc $(0.11$ acre $)$ runoff plots. On the sites studied, runoff occurs only from high intensity summer thunderstorms during the summer months. 
Table 1. Approximate annual water budgets $(\mathrm{cm})$ for various pinyonjuniper treatments at Milford and Blanding, Utah.

\begin{tabular}{|c|c|c|c|c|c|c|}
\hline \multirow{2}{*}{$\begin{array}{l}\text { Location } \\
\text { and treatments }\end{array}$} & \multirow[b]{2}{*}{ Year } & \multicolumn{5}{|c|}{ Measurements ${ }^{1}$} \\
\hline & & $\mathbf{P}$ & I & $\mathrm{R}$ & ET & $\Delta S^{2}$ \\
\hline \multicolumn{7}{|l|}{ Milford } \\
\hline \multirow[t]{3}{*}{ Windrow } & $1969-70$ & 27.74 & 1.96 & 0 & 24.54 & +1.24 \\
\hline & $1970-71$ & 28.96 & 2.97 & 0.30 & 24.64 & +1.04 \\
\hline & $1971-72$ & 22.81 & 3.12 & 0 & 22.17 & -2.48 \\
\hline \multirow{4}{*}{$\begin{array}{l}\text { Debris-in- } \\
\text { place }\end{array}$} & & & & & & \\
\hline & $1969-70$ & 27.74 & 3.17 & 0 & 22.25 & +2.32 \\
\hline & $1970-71$ & 28.96 & 3.30 & 0.05 & 27.53 & -1.92 \\
\hline & $1971-72$ & 22.81 & 4.17 & 0 & 20.60 & -1.96 \\
\hline \multirow[t]{3}{*}{ Woodland } & $1969-70$ & 27.74 & 7.49 & 0 & 20.25 & 0 \\
\hline & $1970-71$ & 28.96 & 7.09 & 0.18 & 21.69 & 0 \\
\hline & $1971-72$ & 22.81 & 6.55 & 0 & 16.26 & 0 \\
\hline \multicolumn{7}{|l|}{ Blanding } \\
\hline \multirow[t]{2}{*}{ Windrow } & $1970-71$ & 23.62 & 2.21 & 3.07 & 16.69 & +1.65 \\
\hline & $1971-72$ & 20.19 & 3.02 & 0 & 15.67 & +1.50 \\
\hline \multirow{3}{*}{$\begin{array}{l}\text { Debris-in- } \\
\text { place }\end{array}$} & & & & & & \\
\hline & $1970-71$ & 23.62 & 2.87 & 0.10 & 20.65 & 0 \\
\hline & $1971-72$ & 20.19 & 4.43 & 0 & 12.73 & +3.05 \\
\hline \multirow[t]{2}{*}{ Woodland } & $1970-71$ & 23.62 & 5.31 & 0.79 & 16.13 & +1.40 \\
\hline & $1971-72$ & 20.19 & 4.90 & 0 & 14.53 & +0.75 \\
\hline
\end{tabular}

${ }^{1} \mathrm{P}$ is precipitation; $\mathrm{I}$ is interception; $\mathrm{R}$ is runoff; $\mathrm{ET}$ is evapotranspiration; $\Delta S$ is change in soil moisture storage. Deep seepage component is equal to zero. Measurements are for the period July 1 to June 30 of each two-year period.

${ }^{2}$ Change in soil moisture storage within $120 \mathrm{~cm}$ (4 feet) soil profile at Milford and within $150 \mathrm{~cm}$ ( $5 \mathrm{feet}$ ) soil profile at Blanding.

\section{Deep Seepage and Change in Soil Moisture Storage}

These variables were determined at each site by techniques described by Gifford and Shaw (1973). Deep seepage was nil during the study period.

\section{Evapotranspiration}

Evapotranspiration (ET) was calculated as the last unknown in the water budget equation:

$$
\mathrm{ET}=\mathrm{P}-\mathrm{I}-\mathrm{R}-\mathrm{DS} \pm \Delta \mathrm{S}
$$

where $\mathbf{P}$ is precipitation, $\mathbf{I}$ is interception, $\mathbf{R}$ is runoff, $\mathbf{D S}$ is deep seepage, and $\Delta \mathbf{S}$ is change in soil moisture storage.

\section{Discussion and Conclusions}

Table 1 shows approximate annual water budgets for pinyon-juniper treatments at Milford and Blanding. The period of study at both sites was reasonably short, and extremes in annual rainfall were not encountered. The range was from a low of $20.19 \mathrm{~cm}(7.95$ inches) at the Blanding site during
$1971-72$ to a high of $28.96 \mathrm{~cm}$ (11.40 inches) at the Milford site in 1970-71. Runoff occurred at both sites only during the 1970-71 period, and these amounts were small, especially at the Milford site. Assuming the data represent a period during which a wide range of climatic extremes (drought, severe runoff-producing thunderstorms, excessive rainfall amounts, etc.) were absent, then precipitation may be utilized approximately as follows within the various pinyon-juniper treatments.

Milford Site

$\begin{array}{llll} & \text { Windrow } & \text { in-place } & \text { Woodland } \\ \text { Interception } & 7-14 \% & 11-18 \% & 24-29 \% \\ \text { Runoff } & 1 \%< & 0.2 \%< & 0.5 \%< \\ \begin{array}{l}\text { Evapotranspiration } \\ \text { Change in soil }\end{array} & 85-97 \% & 80-95 \% & 71-75 \% \\ \quad \text { moisture storage } & \pm 4- \pm 11 \% & \pm 7- \pm 9 \% & 0 \% \\ \begin{array}{l}\text { Deep seepage } \\ \text { landing Site }\end{array} & 0 \% & 0 \% & 0 \% \\ \begin{array}{l}\text { Interception } \\ \text { Runoff }\end{array} & 12-22 \% & 12-22 \% & 22-24 \% \\ \begin{array}{l}\text { Evapotranspiration } \\ \text { Change in soil }\end{array} & 0-13 \% & 0.4 \%< & 0-3 \% \\ \quad \text { moisture storage } & \pm 7-87 \% & 63-87 \% & 68-72 \% \\ \text { Deep seepage } & 0 \% & 0- \pm 15 \% & \pm 4- \pm 6 \% \\ \end{array}$

\section{Deep Seepage Equal to Zero in All Instances}

The magnitude of each process involved in the annual water budget of treatment would be expected to vary depending on the total number, seasonal distribution, size, duration, and intensity of storms received during any given year; environmental conditions during any given storm; and various soil and cover factors. Most annual precipitation on each treatment is lost through evapotranspiration, with much of the balance being lost through interception. However, exact amounts involved in each process are variable among treatments for any given year and within a treatment for different years.

\section{Literature Cited}

Branson, F. A., G. F. Gifford, and J. R. Owen. 1972. Rangeland hydrology. Soc. Range Manage., Range Sci. Series No. 1. 84 p.

Collings, M. R. 1966. Throughfall for summer thunderstorms in a juniper and pinyon woodland, Cibecue Ridge, Arizona. U.S. Geol. Surv. Prof. Paper 485-B. 13 p.

Gifford, G. F. 1973. Runoff and sediment yields from runoff plots on chained pinyon-juniper sites in Utah. J. Range Manage. 26:440-443.

Gifford, G. F., and C. B. Shaw. 1973. Soil moisture patterns on two chained pinyon-juniper sites in Utah. J. Range Manage. 26:436-440.

Skau, C. M. 1964. Interception, throughfall, and stemflow in Utah and alligator juniper cover types of northern Arizona. Forest Sci. $10: 283-287$.

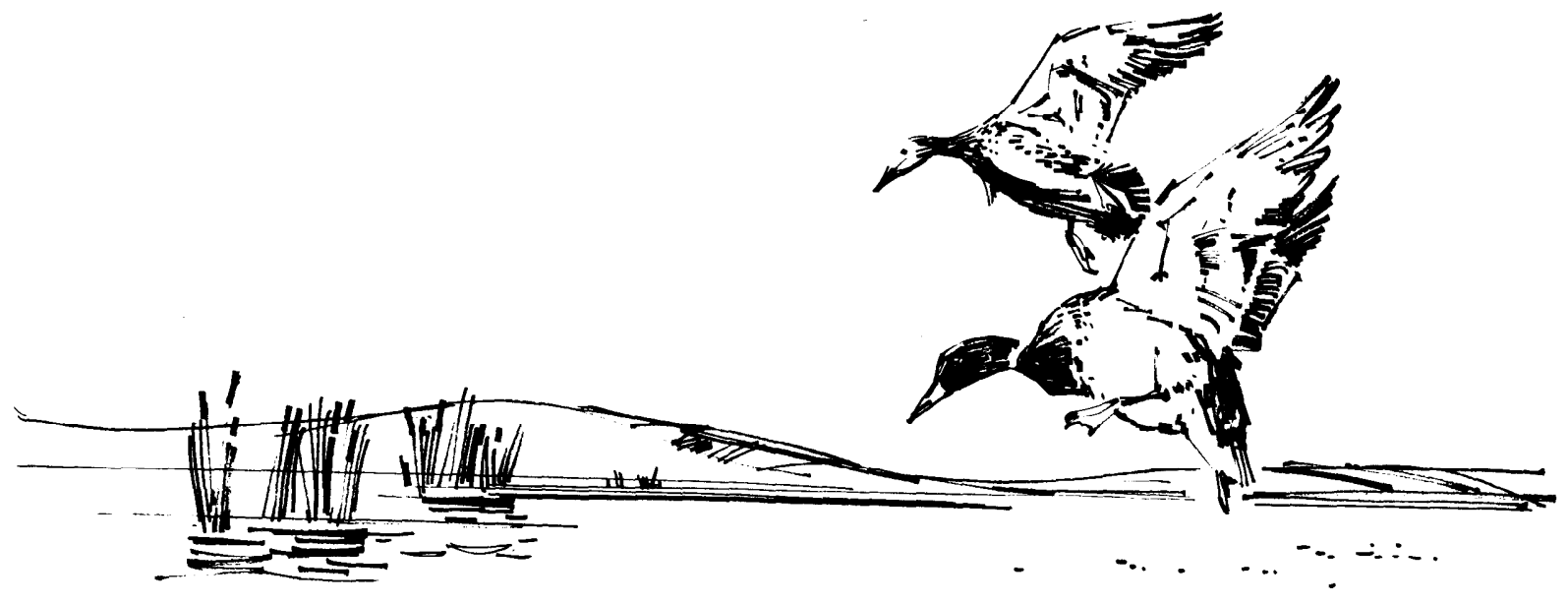

